\title{
Cleaner air in seaport container terminals: assessing fuel(s)
}

\author{
J. M. Vleugel ${ }^{1} \&$ F. Bal ${ }^{2}$ \\ ${ }^{I} T U$ Delft, Faculty of Civil Engineering and Geosciences, \\ The Netherlands \\ ${ }^{2}$ RISSK, Haarlem, The Netherlands
}

\begin{abstract}
Policies to reduce air pollution caused by transport have been practiced in many countries for decades. Maritime transport and seaport areas have been included since the 1990s, with the International Maritime Organisation (IMO) and the MARPOL treaty (1997-ongoing) gradually leading the way to cleaner shipping. Political interest is rising, because maritime and seaport emissions negatively affect the lives of millions of people. Environmental policy may stimulate technical fixes, both end-of-pipe and at the source. Seaport terminal operators may buy more energy efficient equipment, replace diesel by electricity and optimize operations. Ship owners may adapt their fleet to reduce fuel consumption. Less fuel consumed means lower (local) emissions (of $\mathrm{SO}_{2}, \mathrm{NO}_{\mathrm{x}}$, $\mathrm{PM} 10, \mathrm{CO}_{2}$ ) to the air; interesting options, which are increasingly put to good service. A critical assessment of their real impact in a longer timeframe is warranted. In a desk-research study, an input-output model was used to determine the impact of these technical fixes on (local) air pollution. It turns out that their impact can be substantial: reductions in air pollution of $70 \%$ and beyond by ships and terminal equipment. Cleaner air goes in parallel with lower operational costs as well. A green company image also attracts customers. A caveat is that the environmental impact of cleaner fuels is partially compensated by the growth in container transport. Transport is a consequence of logistic choices. Replacing global- by regional or local sourcing/sales and transport optimisation (optimised use of containers) is a worthwhile alternative, which also makes macro-economic sense.
\end{abstract}

Keywords: air pollution, fuels, sea transport, ports, logistics. 


\section{Introduction}

\subsection{Freight transport on the rise}

Transport growth is fueled by a growing world consumption by a growing world population. Then there is cost-driven competition, specialisation/outsourcing, global procurement/sourcing and sales. Production and sales may be separated by thousands of miles. Transport cost is only around $10 \%$ of total production cost [1], so it makes economic sense to pay more for transport, if production cost at a remote location, such as China, is around $10 \%$ or less than in the USA or Europe. Millions of resources, parts, (semi-)finished products and waste are shipped across the world's infrastructures the year round. Containers have become a favourite transport unit, due to cost and quality concerns. Figure 1 shows the growth in container transport for Europe, but other parts of the world are no different.

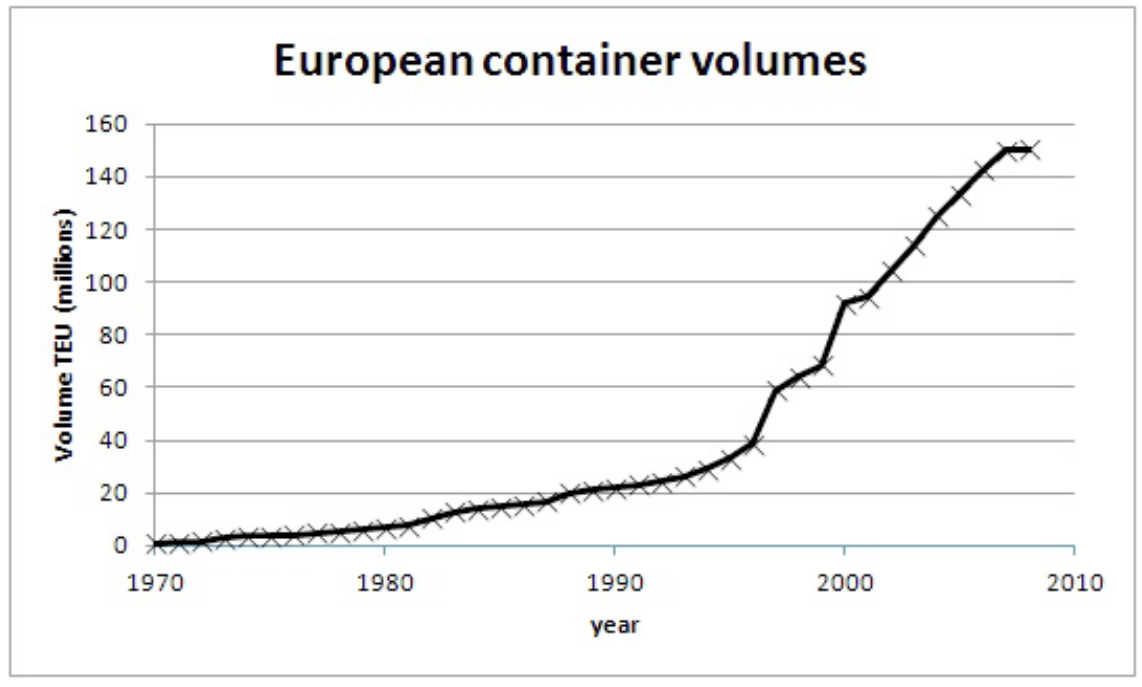

Figure 1: $\quad$ Growth in European container volumes [2].

Sea transport dominates global trade with $95 \%$, corresponding to $3 \%, 30 \%$ and $10 \%$ of global $\mathrm{CO}_{2}, \mathrm{NO}_{\mathrm{x}}$ and $\mathrm{SO}_{2}$ emissions. More transport means more fuel consumption and more of these and other $\left(\mathrm{PM}_{10}\right.$ etc.) emissions (according to IMO, CO-emissions from global shipping would rise from 870 to $2600 \mathrm{mln}$ ton without and to $1600 \mathrm{mln}$ ton without innovative technologies [3]). Sea transport is a low-cost alternative to land or air transport. Economics of scale lead to larger ships, terminals and ports, more and more powerful container handling equipment. What goes in also goes out, which explains growing transport over land and inland waterways. To reduce complexity, hinterland freight transport is not considered in this paper. 


\subsection{Environmental consequences}

Seaports are usually located in metropolitan areas, where millions of people live. They are negatively affected by emissions to the air by (heavy) traffic and transport activities.

Trends in aggregate emissions by container terminals are not published, but statistics for the transport, storage and telecom industry are available.

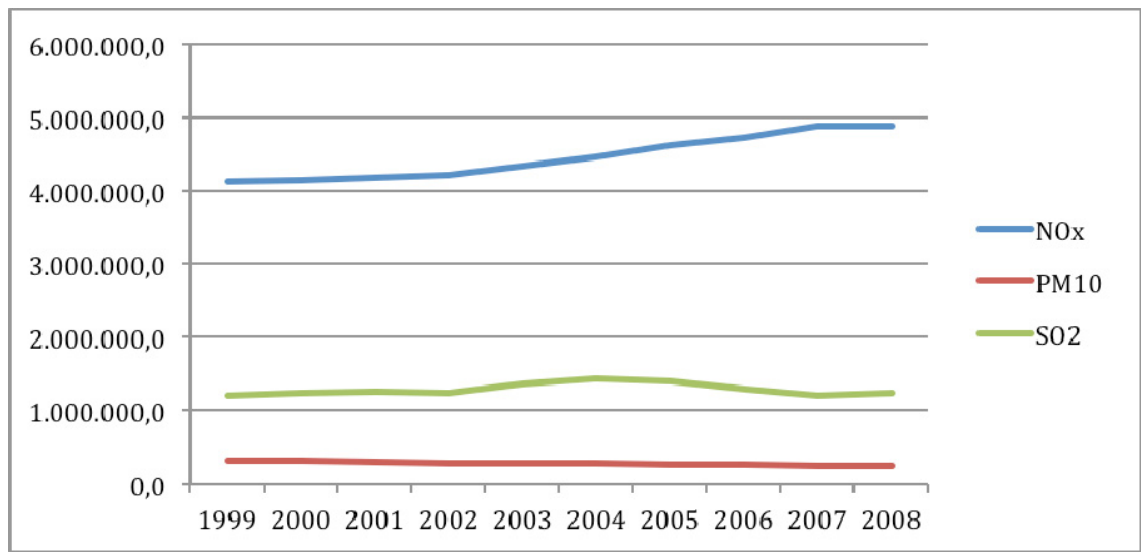

Figure 2: Emissions (in metric tons) to the air by transport, storage and communication industry in EU-27 1999-2008 [4].

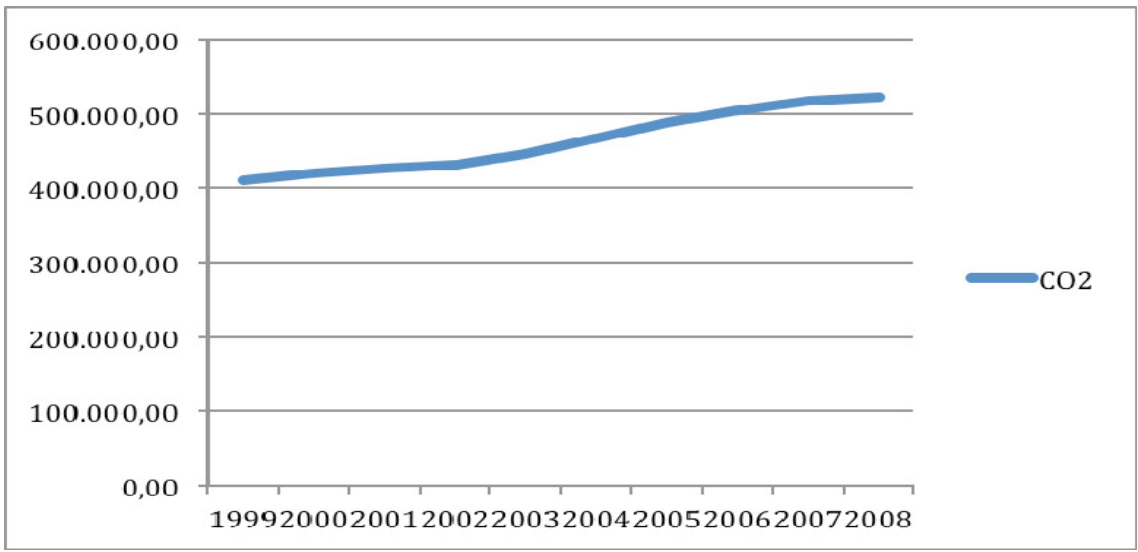

Figure 3: Trend in $\mathrm{CO}_{2}$ emissions (in metric ktons) by transport, storage and communication industry in EU-27 1999-2008 [4]

Figures 2 and 3 show the most recent air pollution data in EU-27. EU-27 is smaller than the 'Europe' of Figure 1, but this will not affect the trends significantly. There are no separate EU-27 transport statistics. It is reasonable to assume that the communications industry has a small, but growing share in these 
emissions. This makes it acceptable to use these data as a proxy for transport. A disaggregation into passenger and freight transport was not available, but it is safe to assume that passenger transport has the largest share in fuel consumption and emissions.

\subsection{Policy, technology and behaviour}

In transport, environmental policies target technological development and user behaviour. Increasingly stricter emission standards are applied for vehicles, which, together with higher fuel prices, stimulate introduction of more energy efficient and cleaner engines in passenger and freight transport. For heavy container terminal equipment, energy efficiency and emission standards have been lacking so far. (Local) air quality standards act as a substitute. This happens for instance in USA (EPA) and Canadian ports. But, also in Australia, Europe and China, air quality and $\mathrm{CO}_{2}$ reduction feature high on the political agenda. The major container terminal operators and ship owners of the world invest in more energy efficient and cleaner technologies, also in response to steeply risen fuel prices - fuel cost may be $50 \%$ of ship operational costs [5] - and fierce competition. Although major improvements per transport vehicle are either introduced or underway [6], the growing number of vehicles and containers mitigate their impact. Figures 2 and 3 show the case of Europe. In the rapidly developing Asian-Pacific region, transport grows much faster, while local environmental conditions may already be (far) less optimal than in Europe.

\section{Scope and aims of the paper}

\subsection{Introduction}

Large volumes of containers are usually transhipped between marine- and land transport vehicles (or v.v.) in a container terminal (Figure 4). Goods are shipped via more than one transport mode, hence the term intermodal transport.

Two process layers are distinguished in the terminal: a primary (container transport equipment, vehicles) and a secondary layer (heating, ventilation, air conditioning, office equipment; not discussed here). The primary layer includes (un)loading of marine vessels, inland ships (barges) and mobile or (semi-) fixed assets, like container cranes. Trucks, trains and barges provide continental transport of containers, but this is not considered in this paper, again to reduce complexity.

\subsection{Research aims and questions}

A first aim is to describe options to reduce (local) energy consumption and air pollution by a container terminal and the sea ships serving it. This answers question Q1: What can seaport terminal operators and shipping companies do to reduce (local) energy consumption and improve (local) air quality? 


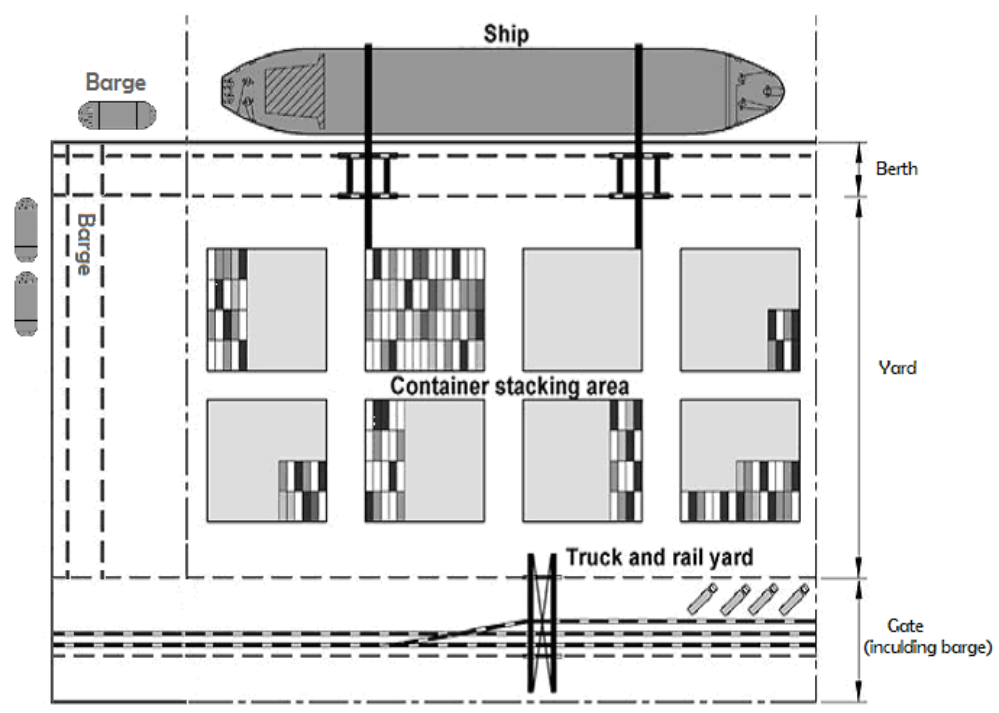

Figure 4: An intermodal container terminal [7].

A next aim is to estimate the potential reduction in fuel consumption and air pollution of implementation scenarios that contain these options. This answers question Q2: What is the potential reduction in fuel consumption and (local) air pollution if packages of these technologies are introduced and used in a certain terminal setting?

A third aim is to elaborate the factors and conditions which stimulate a seaport terminal operator and ship owners to invest in these new technologies. This answers question Q3: Which factors determine the use of more fuel efficient technologies and/or less air polluting fuel sources?

A fourth aim is to assess these options from a financial perspective. This answers question Q4: Do these 'green' investments make financially sense?

Finally, the long-term perspective comes forward, which goes along with question Q5: Are these initiatives sufficient for the environment in a longer-term perspective?

\section{Methodology}

\subsection{A model and its scope}

In order to calculate energy consumption and air pollution by a specific seaport container terminal, a representative model of this terminal had to be developed. The key issue here was that outsiders do not have access to the required dataset, operational procedures and the terminal operations software (TOS). Full-scale modeling is also not practiced by other academics. They concentrate on a small set of operations, like (single) crane movements or stacking of containers. This 
set is then studied under sometimes too simplified conditions. Here, a manageable 'in-between' was to use a combination of public data sources.

\subsection{Options and purpose}

The model allows us to vary the following input parameters:

- container volumes, ship sizes and calls per period;

- terminal equipment;

- energy consumption and emission parameters;

- fuel alternatives and their costs.

The model then calculates the energy consumption and air pollution generated by a set of equipment $h$ used in handling $n$ million containers (p.a.) transported by $m$ ships of various sizes. This input-output model was developed in MS Excel ${ }^{\mathbb{C}}$. It mimics a sequence of movements of containers from the arrival of a ship at the quay and the terminal process until the gate (entry/exit) of the terminal and v.v. For a typical set of container handling equipment, reference average movement times and distances per container were translated into energy consumption data, which were then translated into (aggregated) emission data.

\section{Energy consumption and air pollution}

\subsection{Introduction}

Seaport container terminals are located in coastal areas. These areas emit and receive pollution from various sources and directions, including the sea. Rain and wind carry air pollution. Figure 5 is an example for a nature area, but the processes are similar for built-up areas. A reduction in local air pollution must also involve other countries and other economic sectors. To reduce complexity, only a container terminal and its electricity supplier(s) are considered here.

\subsection{Q1: less energy and cleaner air}

Diesel and electricity are regular fuel sources in a container terminal. To reduce local air pollution, terminal operators may opt for: 1) Electrification: rail mounted cranes usually have electric engines, but where diesel is still used, further electrification is possible. For mobile equipment, conductor bars with automated drive-in option become available. 2) If flexibility and safety are key issues, for some mobile equipment an option is to replace regular diesel by biodiesel, or diesel engines by hybrid-, battery powered engines (e.g. [8]). If an engine upgrade is not technically or economically feasible, this means buying new units, which ideally are more powerful, more energy efficient and less polluting. 3. Redesign of the terminal process and terminal operating software (not considered here).

Ship owners may choose alternative fuels (see 4.4). Ships may sail at half speed (12 instead of 24 knots; slow steaming). Latest generation ships have two small diesel engines instead of one large one, which again saves energy. (Maersk 
mentions $22 \%$ overall bunker fuel savings in 2010 compared to 2007. Dual engine ships like the latest Emma Maersk emit 30\% less $\mathrm{CO}_{2}$ [9].) LNG, fuel cells, hybrid- and nuclear propulsion will become available in future [10].

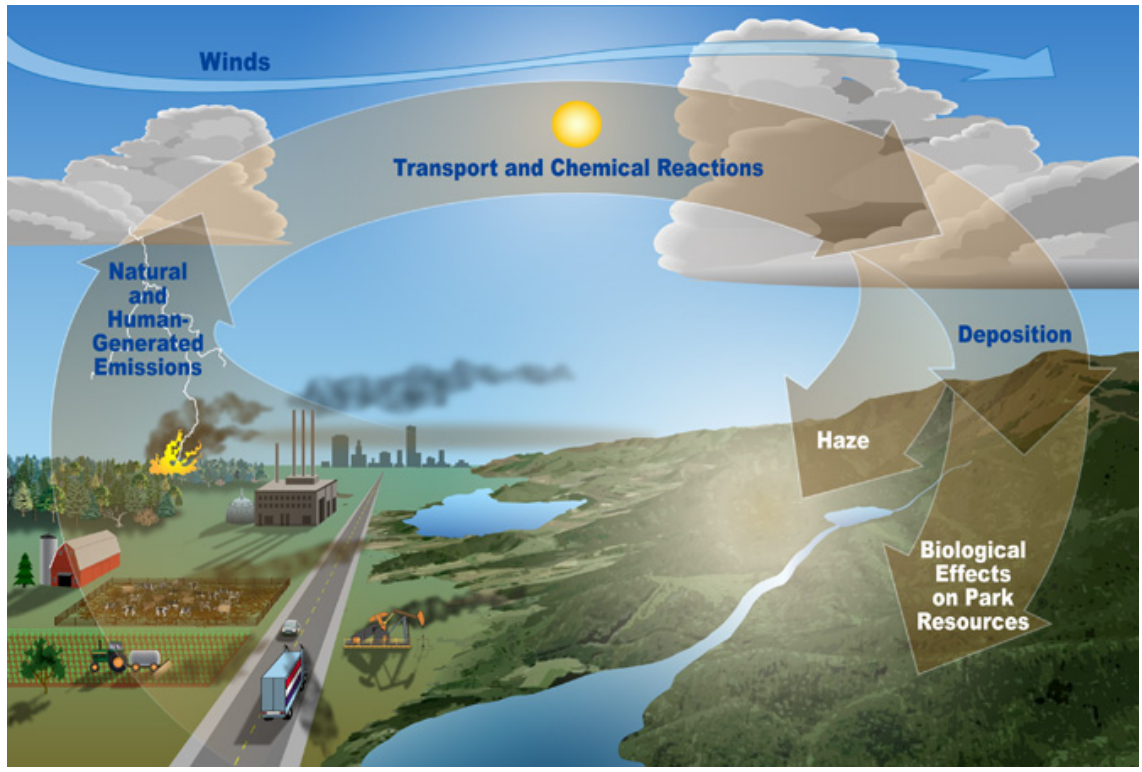

Figure 5: $\quad$ Air pollution is complex [11].

\subsection{Q2: potential reductions}

ECT Delta container terminal (Table 1) located at Rotterdam's Maasvlakte I area is used as an example. It is not the latest design, but already highly automated.

Table 2 shows the environmental impact of various fuels. A mix and volume of sea ship sizes is used that corresponds with a throughput of $3.04 \mathrm{mln}$. TEU per year. The impact of replacing HFO by the more expensive MDO is mixed. HFO and MDO (or MGO) are very different fuels. Engines designed for HFO have to be modified and operated in a different way when used with MDO or MGO. (Investment cost may amount US\$ $1.5 \mathrm{mln}$ per berth and US\$ 400,000 per ship. A ship's energy bill might drop from US\$ 9,600 to US\$ 4,200 per 24 hour stay (assuming $1600 \mathrm{kWh}$ per day, all 2008 data) [12].) In ports, ship engines run at a speed far below the optimal engine speed and (fuel) temperature, which affects any fuel. Replacing grey by green grid power has a decisive impact on ship emissions. Grid power (cold ironing) is an available technology. It requires that ship owners and port authorities invest in the necessary onboard and on shore equipment and power supply [13]. This process is unfolding in several ports, mainly in the USA and Europe.

Table 3 presents $\mathrm{CO}_{2}$-emissions by the land-side activities of this terminal. In the left panel of this table the impact of a greener fuel mix for the Dutch production of electricity can be found. The impact is similar as in Table 2. The 
Table 1: $\quad$ ECT Delta terminal [14].

\begin{tabular}{|l|l|}
\hline Europa-/Amazone port & $265 \mathrm{ha}$ \\
\hline Deep sea quays & $3.6 \mathrm{~km} ; 36$ container cranes; 2 barge cranes \\
\hline Depth of deep sea quay & $16.6 \mathrm{~m}$ max \\
\hline Ship size deep sea quay & Up to $10.000+; 22$ containers wide \\
\hline Barge quay area, cranes & $7.2 \mathrm{ha} ; 3$ barge cranes \\
\hline Barge quay length & $0.37 \mathrm{~km}$ \\
\hline Rail & $18 \mathrm{ha} ; 4$ cranes \\
\hline Containers handled & 3.04 mln TEU ${ }^{1}(2006)$ \\
\hline Available equipment & 38 straddle carriers; 28 multi trailer tractors \\
& 145 multi trailer trains; 9 terminal tractors \\
& 3 reach stackers; \\
& 265 automatic guided vehicles (AGV) \\
& 137 automated stacking cranes (ASC) \\
& 3250 reefer connections (temp. controlled) \\
\hline
\end{tabular}

${ }^{1} 1 \mathrm{TEU} /$ twenty foot equivalent unit has a gross weight of 24 metric ton max. It takes about $2 \mathrm{kWh}$ to move this container with a quay crane (up/down).

Table 2: $\quad$ Cleaner fuels for containerships.

\begin{tabular}{|l|r|r|r|}
\hline $\begin{array}{l}\text { Power sources used } \\
\text { during yard visit: } \\
\text { Manoeuvring/Hotelling }\end{array}$ & $\begin{array}{r}\text { Est. av. level } \\
\text { of } \mathrm{CO}_{2} \text { in } \mathrm{kg} \\
\text { per year }\end{array}$ & $\begin{array}{r}\text { Est. av. level } \\
\text { of } \mathrm{NO}_{\mathrm{x}} \text { in } \mathrm{kg} \\
\text { per year }\end{array}$ & $\begin{array}{r}\text { Est. av. level } \\
\text { of } \mathrm{PM}_{10} \text { in kg } \\
\text { per year }\end{array}$ \\
\hline $\mathrm{HFO} / \mathrm{HFO}$ & $24,020,025$ & 489,050 & 49,903 \\
\hline $\mathrm{HFO} / \mathrm{MDO}$ & $23,237,058$ & 469,476 & 19,318 \\
\hline MDO/HFO & $22,955,426$ & 462,435 & 8,317 \\
\hline HFO/Grey grid & $21,157,301$ & 141,827 & 13,446 \\
\hline MDO/Grey grid & $20,875,669$ & 134,786 & 2,445 \\
\hline HFO/Green grid & $6,354,322$ & 129,375 & 13,202 \\
\hline MDO/Green grid & $6,072,690$ & 122,334 & 2,200 \\
\hline (Change) & $(-75 \%)$ & $(-75 \%)$ & $(-96 \%)$ \\
\hline
\end{tabular}

key differences are 1) that this fuel mix is only available after; 2) several billons of Euros are invested in renewable energy sources, in particular wind parks. In the Netherlands this would take at least until the year 2030.

In Table 4 the impact of another interesting change is shown, namely from regular diesel to biodiesel $\mathrm{B} 30$ and $\mathrm{B} 100$. Biofuels have a modest $\left(\mathrm{CO}_{2}\right)$ to little or even negative $\left(\mathrm{NO}_{\mathrm{x}}\right)$ impact, but give a major reduction in $\mathrm{PM}_{10}$-emissions. The use of biofuels made from primary feedstock has been criticized, because of the (very) negative impact of agriculture on the environment and food prices [15]. Our data show that the consumption of such fuels is not straightforward [16]. A final problem may be a sufficient and reliable supply of biofuels. Biofuels count for only $1.5 \%$ of world diesel production. In dry periods, the USA already experienced biofuel production problems [17]. 
Table 3: $\quad \mathrm{CO}_{2}$-emissions (in $\mathrm{kg}$ ) by container handling equipment.

\begin{tabular}{|l|l|l|}
\hline Electric & 2007 & 2030 \\
\hline Emission factor & $605 \mathrm{gr} / \mathrm{kg}[18]$ & $192 \mathrm{gr} / \mathrm{kg}[19]$ \\
\hline Sea & $22,791,766$ & $7,233,090$ \\
\hline Barge & $4,117,866$ & $1,306,827$ \\
\hline Road & $4,798,506$ & $1,522,832$ \\
\hline Rail & $3,388,805$ & $1,075,456$ \\
\hline ITT & 607,246 & 192,713 \\
\hline All & $35,704,189$ & $11,330,918$ \\
\hline (Change) & & $(-68 \%)$ \\
\hline
\end{tabular}

Note: ITT $=$ Internal terminal transport by multi-trailer.

Table 4: $\quad$ Impact of various diesel alternatives on air pollution (in $\mathrm{kg}$ ).

\begin{tabular}{|l|c|c|c|}
\hline Regular diesel & $\mathrm{CO}_{2}$ & $\mathrm{NO}_{\mathrm{x}}$ & $\mathrm{PM}_{10}$ \\
\hline Sea & $27,219,400$ & 112,986 & 26,381 \\
\hline Barge & $9,246,100$ & 11,578 & 2,716 \\
\hline Road & $6,442,568$ & 26,743 & 6,272 \\
\hline Rail & $4,656,560$ & 19,329 & 4,534 \\
\hline ITT & $1,158,193$ & 4,808 & 1,128 \\
\hline All (1) & $48,722,821$ & 175,444 & 41,031 \\
\hline B30 & & & \\
\hline Sea & $25,346,705$ & 112,885 & 20,472 \\
\hline Barge & $8,609,968$ & 11,568 & 2,107 \\
\hline Road & $5,999,320$ & 26,719 & 4,867 \\
\hline Rail & $4,336,189$ & 19,312 & 3,518 \\
\hline ITT & $1,078,510$ & 4,803 & 875 \\
\hline All (2) & $45,370,692$ & 175,287 & 31,839 \\
\hline (Change 1>2) & $(-7 \%)$ & $(0 \%)$ & $(-22 \%)$ \\
\hline B100 & & & \\
\hline Sea & $24,306,924$ & 116,997 & 7,519 \\
\hline Barge & $8,256,767$ & 11,989 & 774 \\
\hline Road & $5,753,214$ & 27,692 & 1,788 \\
\hline Rail & $4,158,308$ & 20,015 & 1,292 \\
\hline ITT & $1,034,267$ & 4,978 & 321 \\
\hline All (3) & $43,509,480$ & 181,671 & 11,694 \\
\hline (Change 1>3) & $(-11 \%)$ & $(+4 \%)$ & $(-29 \%)$ \\
\hline
\end{tabular}

\subsection{Q3: success or failure factors}

More fuel efficient technologies and/or less polluting fuel sources will be introduced if economically and technically feasible. The economic condition means that the investment should have a reasonable pay-back time and if 
possible also reduce operational costs. This condition can be met, witness the many operators engaged in renewal of terminal equipment (see for instance [20]). The second condition means that container throughput should not be reduced, in particular by less reliable or less powerful equipment. If the technical condition can be met depends on the type of equipment. Electric engines are more reliable and less costly to maintain than diesel engines [21]. If regular diesel is replaced by biodiesel, fuel quality should stay the same. The stability of the electric power supply should also not be compromised if a port is transformed into a major electricity consumer, using $200 \mathrm{MW}$ or more (instead of, for instance, $50 \mathrm{MW}$ at present), comparable to a (small) city. There is growing interest in solar and wind power [22].

\subsection{Q4: financial analysis}

A next issue is the financial benefit of greening of seaport container terminals. This addresses the question: Do these 'green' investments make financially sense? It is not possible to make a calculation for a complete terminal, as key operational and investment data (in particular historic cost of existing equipment) are confidential.

An indication of potential savings based on other sources can be given, however. Replacing a diesel engine in a rubber tyred gantry crane (RTG) by an electric engine saves up to $95 \%$ on diesel and $70 \%$ on maintenance cost. The conversion cost of Euro 150,000 is recovered in 2 years (electric engines have less moving parts, there are no fuel leaks and exhaust fumes, they are easier to regulate, are less noisy and need less maintenance). This is a sound investment with a very short payback period.

It is not so difficult to extend this to a set of n RTGs. Similar calculations can be made for other types of container handling equipment, such as AGV. (AGV's electricity cost may be less than $50 \%$ of diesel fuel costs [23].) If the equipment is close to its estimated end of life, buying new electric replacements is an obvious way to go.

\subsection{Q5: longer-term perspective}

World-wide container transport is likely to continue on its growth path. Everywhere ports are expanding and new ones are underway. In order to channel this process and the negative environmental impact related with clearing the site, construction and use of a terminal, an option is to reduce transport distances by producing more for local instead of global markets. Due to factors like rising labor cost in China, rising transport cost and automation of production, a viable alternative is to relocate production closer to home, in countries like Turkey and Eastern Europe, or in Mexico in case of the USA. This may also help to reduce the major trade imbalance, both in technical terms (shipment of empty containers) as well as in macro-economic terms. 


\section{Evaluation, conclusions and recommendations}

A substantial reduction in energy consumption is feasible per container terminal and container ship. This reduction can be realised with current technology in a relatively short period of time. Major players like terminal operators, ship owners and governments work in that direction. Among alternative fuels the use of biodiesel is under discussion. If made from agricultural (waste) products, biofuels are not good for the environment in any sense. They also have a negative impact on food availability and food prices, which creates an ethical issue. Given this, they do not deserve the label 'renewables'.

The forecasted global growth in container transport is so high that a long-term reduction in emissions will not be realised. This calls for additional measures, in particular non-technical ones. A major cause of the growth in container transport are logistic choices by companies. By changing the popular paradigm towards 'local production for local markets', this growth may be contained to some extent. For regions like Europe and the USA, rising cost of labor and transport in major producing countries like China and changing consumer demand may play a role in this. It may also be very beneficial for these economies, as local jobs may contribute more to the local economy than trade and taxes. In Asia, the (political) situation is different. It is not likely that this region is able or willing to change the trend of growth in (container) transport, because it is related with a growing population and growing wealth and therefore regarded as a necessity or even a basic 'right'. Negative consequences for the environment are then more easily accepted.

While the results are already promising, more can be done in the area of financial analysis of these and future technologies. This is on our future research agenda.

\section{References}

[1] Rodrigue, J-P., The Geography of Transport Systems, $3^{\text {rd }}$ edition, Routledge, New York, 2013.

[2] www.containerstatistics.com/files/pdf/ctsnewsletter_november_2010.pdf.

[3] KIVI NIRIA, De Ingenieur, 2013 (4).

[4] Eurostat Environmental Statistics (website), 2013.

[5] PAE/Holmes, Potential measures for air emissions for NSW ports, A preliminary study for the NSW Office of Environment and Heritage, 2011. h9p://www.worldcargonews.com/htm/w20131223.862257.htm. http://www.carbonpositive.net/industry-updates/382-european-commission -launches-green-efforts-proj... http:/www.joc.com/maritime/apmterminals-cut-emissions-8-percent.

[6] Federal highway administration, Assessing the Effects of Freight Movement on Air Quality at the National and Regional Level, National Freight Transportation Trends and Emissions - Effects Of Freight Movement - Publications - Air Quality - Environment - FHWA.pdf, 2013. 
[7] Brinkmann, B., Operations Systems of Container Terminals: A Compendious Overview, in W. Böse (ed.) Handbook of Terminal Planning, Springer, Berlin, pp. 25-39, 2011.

[8] APMT switches to all-electric Lift-AGVs Port of Rotterdam. http://www.worldcargonews.com/htm/w20120612.843446.htm.

[9] Maersk, http://www.maersk.com/Innovation/WorkingWithInnovation/ Documents/Slow\%20Steaming\%20-\%20the\%20full\%20story.pdf

[10] http://www.nature.nps.gov/air/AQBasics/sources.cfm.

[11] Royal Academy of Engineering, Future ship powering options, Exploring alternative methods of ship propulsion, London, 2013.

[12] Changing from HFO to MDO or MGO: Technological modifications and Procedures, http://www.sailors-club.net/index.php?option=com_myblog\& show=changing-from-hfo-to-mdo-or-mgo-technological-modificationsand-procedures-24175.html\&Itemid $=101$.

[13] The economics of cold ironing, Port Technology International, PT40-24, 2008.

[14] http://myservices.ect.nl/Terminals/rotterdamterminals/deltaterminal/Pages/ default.aspx.

[15] http://www.nrc.n! nieuws/2013/01/05/productie-biobrandstof-1..

[16] Anderson, L.G., Effects of biodiesel fuels use on vehicle emissions, Journal of Sustainable Energy \& Environment 3 (2012), pp. 35-47, 2012.

[17] Biofuels Issues and Trends, US Department of Energy, www.eia.gov, 2012.

[18] Hulskotte, J.H.J., Jonkers, S., Milieueffecten van de Invoering van Walstroom voor Zeecruiseschepen, Riviercruiseschepen en Binnenvaartschepen in de Haven van Amsterdam, TNO-rapport 2008-UR0329/B | 2 |, TNO Bouw \& Ondergrond, Utrecht, the Netherlands, 2008.

[19] Gijsen, A., Spakman, J., Een bestand voor de macro-emissies van het Nederlands elektriciteitsaanbod in 1995, 1998, 2010, 2020 en 2030, Rapport 773001017 , RIVM, Utrecht, 2001.

[20] Maritime Experts Group, Sharing best-practices in reducing greenhouse gas emissions at ports, $32^{\text {nd }}$ Transportation Working Group Meeting, APEC, Singapore, 2009.

[21] http://www.portstrategy.com/features101/port-operations/plan...

[22] Conductix Wampfler (website), wkr0001.pdf.

[23] www.waterkracht.nu. 